\title{
Another Conundrum?
}

\section{Kevin L. Kliesen}

I n 2004, former Federal Reserve Chairman Alan Greenspan expressed surprise that long-term nominal interest rates (e.g., 30-year conventional, fixed mortgage rates) failed to increase as the Federal Open Market Committee (FOMC) increased its federal funds interest rate target. Greenspan and others dubbed this a "conundrum." Today, a different type of financial market conundrum may have arisen: Why, with a high and rising overall U.S. and global inflation rate, has the nominal yield on the 10-year U.S. Treasury security remained below 4 percent for most of the past year?

Long-term Treasury yields often are viewed as a key barometer of inflation pressures. This rationale stems from the Fisher equation, which holds that the nominal yield is the sum of the real yield and a premium to compensate bondholders for inflation and the risk of higher inflation. Accordingly, a rise in 10-year Treasury yields, without a concomitant increase in the federal funds rate, often is attributed to the market's expectation of increased long-term inflation.

The U.S. economy has experienced significant price pressures lately-mostly from the direct effects of large oil, gasoline, and commodity price increases. A sizable decline in the U.S. dollar has also helped to boost prices of nonpetroleum imported goods. The overall effect has been a 4.1 percent annual increase in CPI for 2007 (its highest rate in 17 years) and a 6.2 percent increase in the year to July 2008.

Producers seem to be increasingly able to pass along higher input price increases to offset their shrinking profit margins: The "core" CPI (less food and energy), after averaging 2.3 percent from 2005 to 2007, has increased at a 3.5 percent annual rate over the three months ending in July 2008, which makes the relatively low level and volatility of the 10 -year U.S. Treasury rate even more puzzling.

The chart plots the nominal yield on the 10-year U.S. Treasury security and the FOMC's federal funds target rate, the year-to-year percent change in the CPI, and the University of Michigan's survey of consumers' expectations for inflation over the next 5 to 10 years. Over the past year, the FOMC has aggressively reduced the federal funds target rate against the backdrop of a rapid acceleration in the overall inflation rate. The result is a real federal funds rate of -3.5 percent. At the same time, the 10-year Treasury yield has declined. After the slight increase in consumers' inflation expectations from April to June 2008, expectations have partially reversed. ${ }^{1}$

Why have financial market participants and consumers been so sanguine in the face of these price pressures? First, financial markets may have a "Phillips curve" view of the world-that is, markets may expect much weaker output growth for the rest of 2008 and into 2009 that will dampen inflation pressures. This effect also will tend to reduce the real yield component, so it could have no net effect on expected inflation. Second, the recent decline in energy and commodity prices suggests that the previous price increases were temporary, which may lead to lower overall inflation and, perhaps, eventually eliminate the second-round effects. Some FOMC members favor this view.

Finally, and perhaps most significantly, financial markets and consumers may believe that the long-term inflation rate is significantly lower than the current inflation rate. The implication is that a failure of the current inflation rate to moderate will be aggressively countered by the FOMC to avoid an increase in long-run inflation expectations. However, should the markets lose confidence in the FOMC, the nominal longterm interest rate would likely rise markedly.

${ }^{1}$ Inflation expectations of consumers over the following 12 months rose considerably higher, reaching 5.25 percent in June 2008.

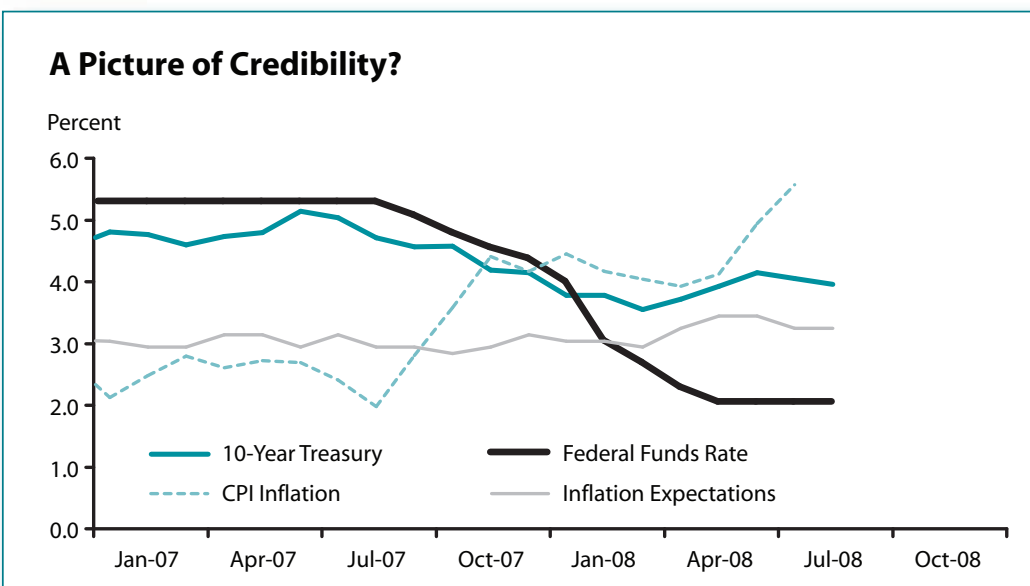

NOTE: The inflation rate is through July 2008; the remaining data are through August 2008. 